\title{
The Risk in the Educational Strategy of Seneca
}

\author{
Stefano Maso (Università CaôFoscari, Venice)
}

To his pupil Nero and to Lucilius (friend and, as metonymy, representative of the entire mankind), Seneca testifies to his pedagogic vocation. With conviction he applies himself to demonstrate the perfect correspondence between the Stoic doctrine and the educational strategy that he proposes. Firstly, the reciprocity of the relationship between educator and pupil appears fundamental; both further their individual knowledge. Secondly, the limitations of an ethical precept that is not anchored in the intensity and concreteness of human life becomes clearly apparent. Furthermore, it brings to question the weakness of a world vision not inspired by an innovative and original path. The starting point is therefore a rigorous examination of conscience to ultimately reach the revolutionary experience of risk in the moment of the last decision. In the name of truth the wise man must have the courage to embrace fate in order to really understand who he is (in a process of oikeiosis both as experience and as target), and he must instil in his pupils the courage to take risks along their own independent journey. In so doing, self-scrutiny and politics can become intertwined. It is herein that the educatorô risk and responsibilities lie.

Thanks to the intercession of Agrippina, the new wife of the emperor Claudius ${ }^{1}$, Seneca had the opportunity to return from Corsican exile.

To Seneca, Agrippina committed the education of his son, the young Nero, so he could learn the overall basis of eloquence, which was considered a necessary art in order to manage power. This opened to the philosopher a double opportunity: first to test directly the value of the pedagogic proposal developed according to the Stoic doctrine, and secondly, to implement the precept according to which the political

\footnotetext{
${ }^{1}$ Agrippina (the Younger) was the sister of Caligula and of Julia Livilla. The latter, daughter of Germanicus and wife of proconsul M. Vinicius, incurred in Messalinaô jealousy, the uncleôs first wife, the emperor Claudius. Accused of adultery she was exiled and eventually sentenced to death (cf. C. Dio 59, 22; 60, 8, 4-5; 60, 31; Sen., Apocol. 10, 4; Svet., Claud. 29). Seneca found himself involved in the matter, it is not clear if as lover or as accomplice of Julia Livilla; for this reason he was sentenced to exile, in Corsica, from which he returned in 49. Cf. Griffin (1976), pp. 59-60; Abel (1985), p. 670.
} 
Journal of Ancient Philosophy Vol. V 2011 Issue 1

commitment is peculiar to wise men. In the first half of the $\mathrm{V}^{\text {th }}$ century AD Joannes Stobaeus, one of the main sources for the reconstruction of Ancient Stoicism, summarizes:

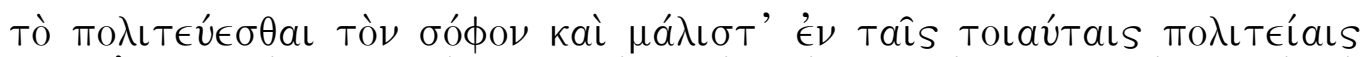

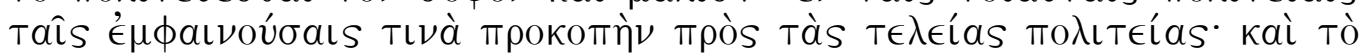

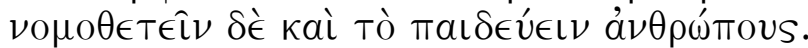

«The sage must go into politics, especially in those States that demonstrate to progress toward perfect government forms: he must also legislate and educate men». (Stob. 2.7, 11b, 10=14 = SVF 3. 611)

In full maturity Seneca finds himself undertaking a great task; the transfer of the most general theoretical assumptions of Stoicism. This inherently involved verification of the presumption that the ethic-social theory of Stoicism was not a pure logical elaboration, but implied a coherent development in the theory of political action (Tò

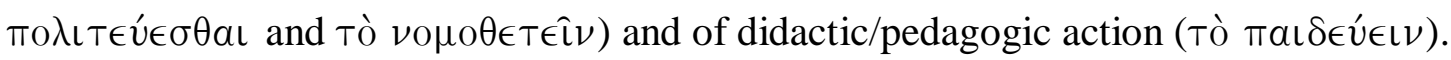

It is not clear that what Stobaeus summarizes above matches the results achieved in the Ancient Stoa. However, it is clear that in Rome with Seneca we find exemplar affirmation. The Ancient Stoa, in fact, mostly concentrated on the study of human nature and questioned whether manôs rationality can exist in harmony with the rationality of the universe ${ }^{2}$. This research resulted in the creation of fundamental elements such as the ópun (the impulse, the appetition), the rá $\theta$ os (the passion), the

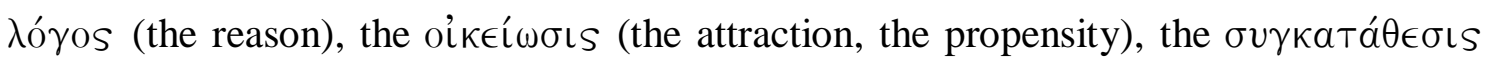

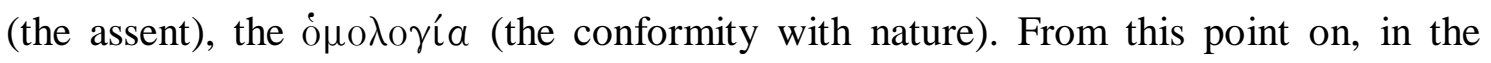
Middle Stoa and, in particular, with Panaetius, the urgency of a practical doctrine rose.

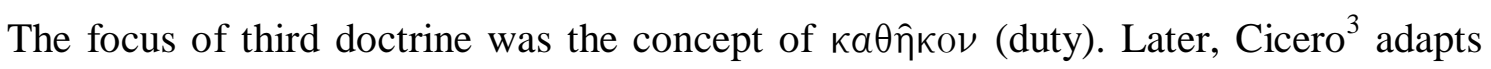
this (and in particular the problem of álutyô to the roman context, favouring a functional interpretation of social ethics and, at the end, of politics tout court.

${ }^{2}$ To the pages dedicated to human psychology by Pohlenz (1992), I, pp. 111-58, it is necessary to add at least the analysis of Inwood (1985), pp. 18-101, and Long (1996), 134-55.

${ }^{3}$ In reality we owe to Cicero the focus of what the Ancient and the Middle Stoa had elaborated in relation to the doctrine of duty. In the De officiis in particular, Cicero certainly declines his inquiry in direction of a social application: cf. De off. 1, 9. On this see Inwood (2005), pp. 11419. On Panaetius and on his presumed reinterpretation of the theory of action cf. now Alesse (1994), pp. 74-83. 
Journal of Ancient Philosophy Vol. V 2011 Issue 1

With Seneca it is ultimately necessary to highlight a new aspect: for the philosopher/preceptor it is not only a matter of testing the doctrine of power in a q́assiveô dimension, that for which the wise man is the one who knows how to resist to suffering and remain «constant» in the face of adversities, accepting with steady heart whatever fate reserves for him; it is also necessary, to measure the efficacy of the doctrine in the áonstructiveô phase. This phase occurs in the moments in which the strategies employed and the decisions reached are based in sapiens «agreement» with fate: in other words he recognises the line of his development and sets himself to willingly bring it about.

It is an issue of no small importance. In fact it is about educating oneself and

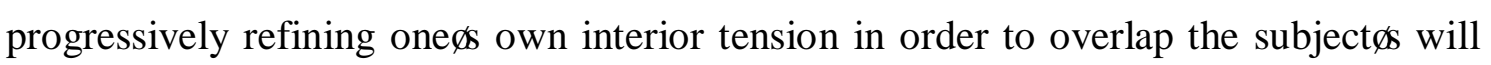
with the line of tension of all. Thus, in small stages, all the desires that feed the individual tension will no longer be irrational, but are brought back to their natural function, in harmony with the balance of Nature. And because (for his nature) man is not himself evil, there should be no particular problems in his education and guidance along the correct course. So when it is read:

Neminem mihi dabis qui sciat quomodo quod vult coeperit velle: non consilio adductus illo sed impetu inpactus est (Ep. 37, 5),

it must be understood that at the origin there is an instinctive tension but after, on that it is grafted deliberation, there exists conscious will of deciding this or that, of realizing a certain desire or of banning another.

From this, therefore, the importance of an education that is capable of recovering rationally what a man, at first, non-rationally feels in himself. We must take note of this important notation; and since, as it has already been observed, man belongs to the development of the perfectly balanced natural totality, it happens that the interior impulse (impetus) will only originally be positive. In fact, for this reason (that is for this good original nature) man can find within himself the key to defend from evil and to consciously and absolutely want good: 
Journal of Ancient Philosophy Vol. V 2011 Issue 1

Quidque facere te potest bonum tecum est. Quid tibi opus est ut sis bonus? Velle. (Ep. 80, 3-4).

That is: Will becomes the method with which rational control is translated into the a-rational forms of desire, the tool that allows to every single human being to become really «wise», which the truth of everything shows itself through, the truth of Fate that deterministically and unavoidably states itself ${ }^{4}$.

Among the teachers that Seneca had in his youth, three are always remembered with high respect and admiration: Sotion of Alexandria (belonging to the School of Sextii), Attalus (Stoic) and Papirius Fabianus (also linked to the school of Sextii) ${ }^{5}$. It is very probable that they have influenced the precise direction of a positive view and áctiveôStoicism. On one hand the Pythagoric tradition from which the School of Sextii took inspiration makes central the moment of formation: a real training of the person toward the control of his body and his mind in relation to Nature and the surrounding reality. Starting with this exercise, a severe attention toward onê̂ life condition should be developed and, so, a thoughtful attitude towards human relations.

On the other hand: the real Stoic course, according to which the structure of natural reality, organised on the basis of a logical and physical necessity, in itself should have put man in the right place and in the right disposition to allow him to express his own virtue.

This entails a progressive knowledge of oneself as well as of Nature and its rules.

Seneca, in a passage of De ira, shows the importance of the exercise of «reason» in self-control and how decisive the teaching of the School of Sextii ${ }^{6}$ was. Senses can be

\footnotetext{
${ }^{4}$ For a more analytic discussion about these points I refer to Inwood (2005a), pp. 132-41, and to Maso (2006), pp. 15-21 and 26-39.

${ }^{5}$ Cf. Griffin (1976), pp. 36-43; Abel (1985), pp. 661-64. About the school of Sextii cf. Lana (1973), pp. 339-89; in particular, on the aspect as áctiveômanner of speaking that allows the realization of a «very high ideal», pp. 341-42.

${ }^{6}$ In Nat. q. 7, 32, 2, Seneca quotes the School of Quintus Sestius and of his son Sestius Niger (I c. BC.) reminding its importance and the originality within the roman tradition and feeling sorry
} 
Journal of Ancient Philosophy Vol. V 2011 Issue 1

stabilised if the mind is balanced; but the mind will be such a condition and will not anger if it knows that after, it will have to report daily to reason:

Omnes sensus perducendi sunt ad firmitatem; natura patientes sunt, si animus illos desît corrumpere, qui cotidie ad rationem reddendam uocandus est. Faciebat hoc Sextius, ut consummato die, cum se ad nocturnam quietem recepisset, interrogaret animum suum: 'quod hodie malum tuum sanasti? Cui uitio obstitisti? Qua parte melior es?' Desinet ira et moderatior erit quae sciet sibi cotidie ad iudicem esse ueniendum. (De ira 3, 36, 1-2)

Through the frequentation of Sotion and of Papirius Fabianus ${ }^{7}$, Seneca learned and adopted such a precept. He demonstrates its scrupulous application describing the intimacy of a family scene in which he usually acts: it is already evening, the last lamp has been taken from the room and his wife is finally quiet, conscious of the fact that her husband, engrossed in darkness and silence, starts his own examination of conscience. He intends to judge himself going through his own errors; rather than to focus the best or most correct strategy of practice in human relations:

Quicquam ergo pulchrius hac consuetudine excutiendi totum diem? Qualis ille somnus post recognitionem sui sequitur, quam tranquillus, quam altus ac liber, cum aut laudatus est animus aut admonitus et speculator sui censorque secretus cognouit de moribus suis! Vtor hac potestate et cotidie apud me causam dico. Cum sublatum e conspectu lumen est et conticuit uxor moris iam mei conscia, totum diem meum scrutor factaque ac dicta mea remetior; nihil mihi ipse abscondo, nihil transeo. Quare enim quicquam ex erroribus meis timeam, cum possim dicere: 'uide ne istud amplius facias, nunc tibi ignosco. In illa disputatione pugnacius locutus es: noli postea congredi cum imperitis; nolunt discere qui numquam didicerunt. Illum liberius admonuisti quam debebas, itaque non emendasti sed offendisti: de cetero uide, non tantum an uerum sit

for its premature closing: Sextiorum nova et Romani roboris secta inter initia sua, cum magno impetu coepisset, extincta est.

${ }^{7}$ According to Senecaôs texts Sotion turns out to have being a trusty interpreter of the teachings of the School of Sextii, attentive in particular to the control of oneô own body, to diet, in order to guarantee a correct relation among all the living beings, independently from the soul survival after death; cf. ep. 108, 18-21. Papirius Fabianus instead transmitted to Seneca most of all the admiration for the Ancients and for the practical consistency of his Ethics proposal, (ep. 100, 112), both in educational field (mores ille, non verba composuit et animis scripsit ista, non auribus) and in politic field (Fabiani Papiri libros qui inscribuntur civilium legisse te cupidissime scribis). 
Journal of Ancient Philosophy Vol. V 2011 Issue 1

quod dicis, sed an ille cui dicitur ueri patiens sit: admoneri bonus gaudet, pessimus quisque rectorem asperrime patitur. (De ira 3, 36, 2-4)

Only when the consciousness of being is in balance with the natural unfolding of world events (to which he belongs) can man be quiet and free. There are no debts; the language of law (ad rationem reddendam vocare, interrogare, ad iudicem venire, excutere, recognitio, speculator, censor, cognoscere, potestas, causam dicere, scrutare, remetiri, error, ignoscere, emendare, offendere) confirms the register that Seneca has adopted and the line along which he is moving. In the internal conversation with himself - a conversation that must occur daily because it is strictly linked to a training practiced tenaciously - Seneca structures his own personality and defines a method to educate himself. Praise and admonishment are part of the strategy. So, as with the self-precept technique, the real aim is seen only in the background and must be taken back to the perfect virtus from which the sapiens tends for his nature.

Seneca, in other words, is the living witness of a real and true paradox: he «is» wise (because he has consciously made virtus his reason of being) and, at the same time, «he must continue to be» wise. If the condition of Stoic sapiens is not, in roman contest, once and for all achieved, but it is such if and only if it is continuously witnessed in action; a self-check on internal action and, as necessary consequence, a willing to open toward the exterior. Seneca in fact will continue the day after day (and so every áomorrowôof his life) to discuss, to educate, to write, to propose the Stoic doctrine as a life strategy. He will transpose his internal experience from its initial form to wisdom. In this prospective he clearly shows himself as an original interpreter of the stoic doctrine of Ethics, perhaps a predecessor of that philosophic-practical áctiveôthought that will find in Epictetus one of its main ${ }^{8}$ characters.

Certainly in the educational strategy the reciprocal availability and willingness of both teacher and pupil is necessary. This means the recognition of the other and of

\footnotetext{
${ }^{8}$ Long (1971), pp. 173-99, misses the centrality of Senecaô position: the scholar, pp. 189-92, finds in Epictetus the first and the main interpreter of this new moral attitude.
} 
Journal of Ancient Philosophy Vol. V 2011 Issue 1

the distinct roles that each individual unfolds. Seneca remembers with precision the walks himself and his teacher Attalus took, and the consequent discussions that allowed both to improve and progress along the path of wisdom. Enjoying time with a philosopher always brings some benefit, just as, under the sun, one tans even if he did not want to; or as when one, that stops a little in a perfumery, exits followed by scent:

Haec nobis praecipere Attalum memini, cum scholam eius obsideremus et primi veniremus et novissimi exiremus, ambulantem quoque illum ad aliquas disputationes evocaremus, non tantum paratum discentibus sed obvium. 'Idem' inquit 'et docenti et discenti debet esse propositum, ut ille prodesse velit, hic proficere.' Qui ad philosophum venit cotidie aliquid secum boni ferat: aut sanior domum redeat aut sanabilior. Redibit autem: ea philosophiae vis est ut non studentis sed etiam conversantis iuvet. Qui in solem venit, licet non in hoc venerit, colorabitur; qui in unguentaria taberna resederunt et paullo diutius commorati sunt odorem secum loci ferunt; et qui ad philosophum fuerunt traxerint aliquid necesse est quod prodesset etiam neglegentibus. Attende quid dicam: neglegentibus, non repugnantibus. (Ep. 108, 3-4)

Did Seneca expect this from Nero? Did he expect to speak with a pupil not hostile to the values of philosophy? Did he expect to experience such a constructive relationship for himself?

Does he expect this from Lucilius?

In effect both Nero and Lucilius are the most important recipients of the project and of the pedagogic action of Seneca. A cultured man, Seneca applies himself both toward his direct pupil and toward humanity at large, personified by his younger friend Lucilius. He imagines being able to admonish and correct the nature of the future emperor through a call to philosophy and also through the exercise of rhetoric and literary art. This broadens the horizon to humanity in its global aspect, he proposes to himself to add to the education, wisdom and virtue of any man that áloes not oppose or put up resistanceô(non repugnans) to philosophy.

In Nerô̂ case Seneca will operate in very delicate conditions. The pupil, when young, will still be perceptive to his calls, the application of an elementary teaching by precepts will appear sufficient. This is the same type of teaching by precepts that 
Journal of Ancient Philosophy Vol. V 2011 Issue 1

initially Isocrates had used to teach the moves of fight to his disciple, but that his pupil, a little at time, had started to apply by himself ${ }^{9}$. Following this, in the moment of the succession to throne, the necessity to give solid support to an emperor that has the responsibility to act and decide for the good of his people becomes pertinent. At this level teaching by precepts is no longer enough, it necessitates that the practice of philosophical theories acquired and assumed the rule of behaviour. It would be

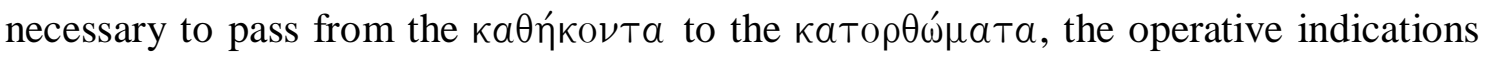
concerning the direct knowledge of the correct path. But with the young Nero any effort seems useless, it is not enough to warn him from the negative outcome of anger ${ }^{10}$ or to suggest to him the use of clemency ${ }^{11}$. Neither is the ingenious strategy of proposing to Nero a gloomy representation of reality successful. This reality corresponds to a representation born in the tragedies; many scholars believe in fact that Seneca decided to compose them with a specific moral and pedagogic intent, to display evil in its most dramatic forms in order to avoid its practice. To the exhibition of the human being álestructionôshould be able to oppose the áffirmationôof the positive hero. It is instead

\footnotetext{
${ }^{9}$ Seneca does not seem to know Isocrates: perhaps he evokes it in tranq. a. 7.2, if we accept the correction ad loc. of Erasmus; in that passage Seneca is underlining how important is that the teacher fully understands the real aptitudes of the pupil: considerandum est, utrum natura tua agendis rebus an otioso studio contemplationique aptior sit, et eo inclinandum, quo te vis ingenii feret. In any case it is important to understand how the greek paideia could be influenced inside the Stoic educational project in the roman contest; so promised Isoc., ad

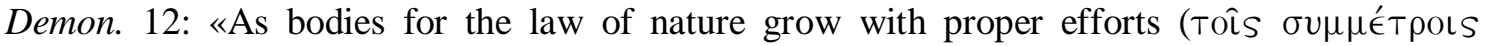

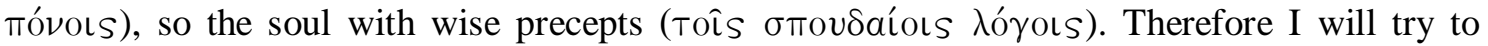
briefly suggest you through which practices $\left(\delta \iota^{\prime} \hat{\omega} \nu\right.$ é $\left.\epsilon \pi \iota T \eta \delta \epsilon \nu \mu a ́ \tau \omega \nu\right)$ you can do huge progress along the way of virtue and enjoy good fame among all other men».

${ }^{10}$ The dialogue De ira very probably had already been composed when Seneca had the charge of preceptor of Nero. It so could be dated back to $41 \mathrm{AD}$, after the death of the emperor Tiberius and before the exile. In any case the name of the recipient, the brother Novatus, indicates that at the time he had not received yet the new patronymic following the adoption (52 AD) by his teacher of rhetoric Junius Gallio. Cf. Giancotti (1957), pp. 98-102; Griffin (1976), pp. 396-98; Abel (1985), p. 705.

11 The De clementia (written between December of 55 and December of 56) is directly dedicated to Nero. Cf. in particular Griffin (1976), pp. 407-11, Malaspina (2005), pp. 6-8, and Braund (2009), pp. 16-23. Regarding the underlying moral for which the politic clemency and the clemency of judge must transform in an authentic prodesse toward subjects and toward man in general, cf. Bellincioni (1984).
} 
Journal of Ancient Philosophy Vol. V 2011 Issue 1

the Stoic sapiens the one to imitate ${ }^{12}$. So, along with the áxemplar preceptsôoffered to Nero in the De clementia, to which it is necessary to set aside the psychological stimulus represented by the positive hero to imitate, comes together as antithesis the óbsessiveôdescription of evil that can derive from a bad use of power ${ }^{13}$. On one hand the ógood princeô on the other the áyrantô

As we know, Seneca is absolutely conscious of the difficulties of his task; he knows the court environment and the innate problems of translating into practice the moral teachings of Stoicism. He helps Nero in any way possible to realize a civil project useful to the People ${ }^{14}$, and facilitates independence from his mother Agrippina. However, in the end, the operation fails and the amicus principis has to abandon his role as a tutor, as a teacher and then as counsellor ${ }^{15}$.

The situation for Lucilius is completely different. After renouncing the role of educator and counsellor of the prince, Seneca rediscovers his deepest inspiration, reopening the games addressing humanity through Lucilius. This must be interpreted from Epistulae; but the same thing must be done regarding the seven books De

${ }^{12}$ Abel writes (1985), pp. 767-68: «Die tragischen Themas Senecas zerfallen in zwei Gruppen; die moralische Selbstbehauptung ist der Vorwurf des ótercules furensô óOedipusô und der ó rroadesô die moralische Selbstzerstörung ist Leitthema in der óMedeaô dem óAgamemnonô und óThyestô Die ớPhaedrâ̂ nimmt eine Zwischenstellung ein, indem sie die Heldin zum großgeschauten Sinnbild der Vernichtung und Wiederaufrichtung der sittlichen Würde macht». Dingel (1974), pp. 72-120, defines the world represented in Senecaôs tragedy as the place of the authentic Negation der Philosophie. Fitch \& McElduff (2008), pp. 157-80, return on the áonstructiveôand training elements of tragedy.

${ }^{13}$ Viansino (2007), I, in partic. pp. 6-10, insists very effectively on the educational-politic function of tragedy.

${ }^{14}$ For the influence and the success of Seneca and of Afranius Burrus as ministers during the socalled quinquennium Neronis, (54-58) I remand to the discussion about the witnesses of Tacitus and of Cassio Dio present in Griffin (1976), pp. 67-128. More generally, cf. Scullard (1970), pp. $315-18$.

${ }^{15}$ The failure becomes complete with the suicide which Seneca is obliged to. Tacitus comments, Ann. 15, 62-64: Cui enim ignaram fuisse saevitiam Neronis? Neque aliud superasse post matrem fratremque interfectos, quam ut educatoris praeceptorisque necem adiceret. 
Journal of Ancient Philosophy Vol. V 2011 Issue 1

beneficiis dedicated to the friend Aebutius Liberalis and with the majority of Dialogi ${ }^{16}$. Seneca in an epistle of the first book of the collection addressed to Lucilius declares to retire to a more private life in order to devote himself to posterity (posterorum negotium ago). He says to have verified himself carefully through the efficacy of medicines (in meis ulceribus expertus) and claims to now be able to indicate, in old age, the correct way to follow (rectum iter ... aliis monstro):

In hoc me recondidi et fores clusi, ut prodesse pluribus possem ... Secessi non tantum ab hominibus sed a rebus, et inprimis a meis rebus: posterorum negotium ago. Illis aliqua quae possint prodesse conscribo; salutares admonitiones, velut medicamentorum utilium compositiones, litteris mando, esse illas efficaces in meis ulceribus expertus, quae etiam si persanata non sunt, serpere desierunt. Rectum iter, quod sero cognovi et lassus errando, aliis monstro. (Ep. 8, 1-3)

His own experience is fundamental; to Seneca it is no longer a matter of transposing immediately, that is a direct application of the ethic-social theory of Stoicism; instead he believes that the right moment has arrived for a great leap and imagines himself as counsellor and teacher for future generations ${ }^{17}$.

Two letters specifically refer to this. The 94 and the 95 both have a particular function; primarily they are very large, totalling 147 paragraphs when combined. With the short letter 93 (only 12 paragraphs) acting as an introduction, they compose the

${ }^{16}$ The treatise De beneficiis according to the internal clues and to series of indications derivable most of all from the Epistulae, has to be set in the period that follows Senecâ̂ retirement from power; mostly in 62/63. Cf. Préchac (1972), pp. I-XXVII. Griffin agrees (1976), p. 399. The topic faced and the moral proposal connected, cfr. Abel (1985), pp. 734-38, and, overall, Chaumartin (1985), pp. 157-94: the scholar analyzes the relation preceptor/pupil underlining the critical points in the relation between Seneca and Nero. It is interesting to note that the treatise includes in itself aspects and argumentation that concern both to the concrete moral problems of individual and more generally to the social-politic environment, and that in respect of Seneca committing himself to interpret the Stoic theory. On this Inwood (2005b), pp. 65-94. Referring to Dialogi, even for them it is necessary to imagine an universal óecipientôbeyond the specific friends or relatives which they are occasionally dedicated to: Lucilius, Serenus, Novatus (= Gallio), Marcia, Paulinus, Polybius, Helvia.

${ }^{17}$ Seneca specifies that the task to give advice does not only concern to pedagogue, as thought by the Stoic Aristo of Chios, but all the more to philosopher, that is to wise man: who is he if not the pedagogue of human being? Nam eum locum qui monitiones continet sustulit et paedagogi esse dixit (Ariston Chius), non philosophi, tamquam quidquam aliud sit sapiens quam generis humani paedagogus, ep. 89, 13. 
Journal of Ancient Philosophy Vol. V 2011 Issue 1

book XV of the letters. The letter 93 poses a question; what is the right duration in order to define a well-accomplished life? Seneca stresses that everyone inhabits the time they are supposed to ( $\$ 6$ habeo meum); what is necessary and useful is only the time that is required to reach wisdom ( $\$$ 8: Quaeris quod sit amplissimum vitae spatium? usque ad sapientiam vivere).

But the real point is this: how can one obtain wisdom in the time that is granted to us? Here we find a real treatise of pedagogy, at the core of which is a technical issue of strategical importance: should the education to wisdom be established on decreta or on praecepta? What is the correct use of the former and which is the most effective of the latter? Is there an interaction between the two?

Utrum utilis an inutilis sit (scil. scientia praeceptorum), et an solus virum bonum possit efficere, id est utrum supervacuus sit an omnis faciat supervacuos. (Ep. $94,4)$

It is clear that the decreta, that Seneca also indicates as scita or placita (ep. 95,

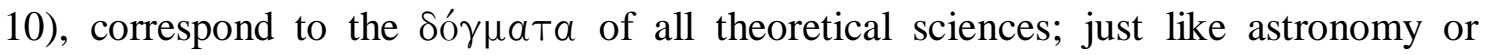
geometry, also the ars contemplativa (that is the theoretical study of philosophy) has its own principles. They aim to indicate that the general principles ${ }^{18}$ applied to action are no doubt recta et honesta (ep. 94, 32). In reference to this, the action of the wise man

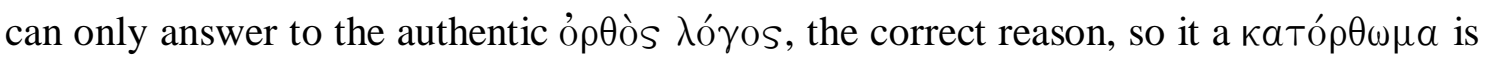
necessary as an action directed to rectitude.

Therefore it is possible to perceive, between the folds of this argumentation, a logical development, on the basis of which we can find the indissoluble relation between wisdom and correct action. This is the conclusion that, according to Seneca, belongs to the Stoic Aristo of Chios. For whom:

\footnotetext{
${ }^{18}$ Seneca sustains that decreta philosophiae are practically a sort of generalia praecepta (ep. 94 , 31). These ones are opposite to specialia praecepta. Both «teach»: utraque res praecipit, sed altera in totum, particulatim altera. It seems to be a convergence, if not an underlying identity, for which ones without the others cannot be efficient, cf. Bellincioni (1978), pp. 87-116; Ioppolo (2000), pp. 15-18; Schafer (2009), pp. 105-09.
} 
Journal of Ancient Philosophy Vol. V 2011 Issue 1

Plurimum ait proficere ipsa decreta philosophiae constitutionemque summi boni; 'quam qui bene intellexit ac didicit quid in quaque re faciendum sit sibi ipse praecipit'. (Ep. 94, 2)

These words are followed by the eloquent example of a javelin; whoever has to throw it, trains himself in moving the arm and aiming towards a series of targets. When the trainee is confident, he will be able to hit not only the series of targets that were used during the training, but any target (quocumque vult), without having to be taught the particulars (non desiderat particulatim admoneri, doctus in totum, ep. 94, 3).

At first, the position of Aristo appears defendable. However, for Seneca this is not the case. On one hand, between theory and praxis there is a very clear discrepancy ${ }^{19}$; on the other, the wise man was not born wise, but he has had to become so progressively. According to this it is necessary that decreta and praecepta appear and

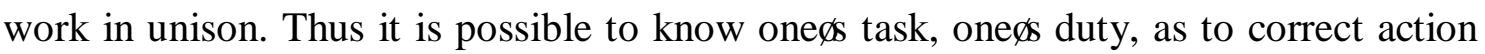
(като́ $\rho \theta \omega \mu$ ). But this is not immediately followed by the specification:

Hic quoque doctus quidem est facere quae debet, sed haec non satis perspicit. (Ep. 94, 32)

We must also consider other factors linked to the environmental and socialhistorical context in which one lives, and importantly, the different stages along the path toward wisdom that everyone walks. Seneca openly speaks about proficiens to indicate those who are walking toward wisdom; it is a path that can be so long that could last a lifetime and that can even develop, step by step, in a congenial way according to the different stages of life, from childhood through to old age $\mathrm{e}^{20}$. The proficiens is someone who is learning how to live for his entire life: tamdiu discendum est quemadmodum

${ }^{19}$ Sen., ep. 94, 48: 'Philosophia' inquit 'dividitur in haec, scientiam et habitum animi; nam qui didicit et facienda ac vitanda percepit nondum sapiens est nisi in ea quae didicit animus eius transfiguratus est.

${ }^{20}$ Ep. 121, 15: Quomodo ergo infans conciliari constitutioni rationali potest, cum rationalis nondum sit?' Unicuique aetati sua constitutio est, alia infanti, alia puero, 〈alia adulescenti>, alia seni: omnes ei constitutioni conciliantur in qua sunt. Consequently, to be proficientes means always to be on the way, «sempre in cammino, e in una tensione continua delle forze la quale consenta di procedere anziché di regredire», Bellincioni (1978), p. 81. 
Journal of Ancient Philosophy Vol. V 2011 Issue 1

vivas quamdiu vivas, (ep. 76, 3). Thus the elder will also have something to learn: etiam seni esse discendum (ibid.).

It is clear that if someone is a proficiens, they are one that has not received yet a complete training. Therefore he cannot own all the requirements of knowledge, in a simply deductive way:

quando oporteat et in quantum et cum quo et quemadmodum et quare. (Ep. 95, 5)

It is those more specific praecepta that he needs, those that only the wise preceptor (or the teacher or the counsellor) will be able to propose him. Unlike the thinking of Aristo, decreta is not sufficient; on the other hand neither praecepta alone is sufficient. That is, those warnings which indicate, circumstance by circumstance, what

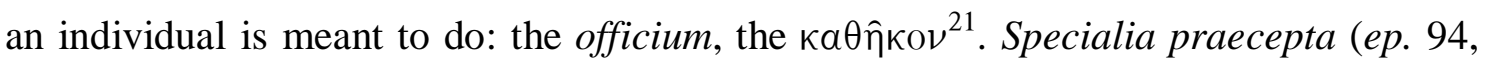
31). These are themselves endless, since the different circumstances in which they occur are endless. Consequently, if someone thought of having to always decide only on the basis of detailed and personalized instructions, he would risk being unable to act or to proceed on his own. Seneca is explicit regarding this, he does not hesitate to suggest that to allow every proficiens to catch sight of his own path the purpose of an educational project. Certainly the teacher will be sensitive to character differences, for in some cases he intervenes with the necessary iudicium: hoc vitabis, hoc facies (ep. 94, 50). In particular the weaker characters will tend to hesitate to take the initiative on their own. They lack confidence to the point that they risk losing sight of the real good: wisdom. It is right, in these cases, to intervene:

Inbecillioribus quidem ingeniis necessarium est aliquem praeire: 'hoc vitabis, hoc facies'. Praeterea si expectat tempus quo per se sciat quid optimum factu sit, interim errabit et errando inpedietur quominus ad illud perveniat quo possit se esse contentus: regi ergo debet dum incipit posse se regere. (Ep. 94, 50-51)

\footnotetext{
${ }^{21}$ As it is known, the roman pedagogic literature recovered from the philosophy of Panaetius of Rhodes the topic of «duty»: not only the De officiis of Cicero is constructed referring to the

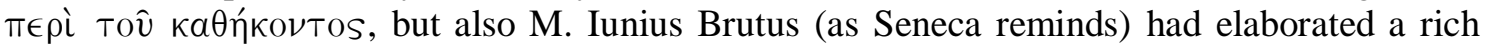
education based on precepts addressed to parents, to children and brothers: M. Brutus in eo libro quem $\pi \epsilon \rho \grave{~ \kappa a Ө \eta ́ \kappa о \nu т о s ~ i n s c r i p s i t ~ d a t ~ m u l t a ~ p r a e c e p t a ~ e t ~ p a r e n t i b u s ~ e t ~ l i b e r i s ~ e t ~ f r a t r i b u s, ~ e p . ~}$ $95,45$.
} 
Journal of Ancient Philosophy Vol. V 2011 Issue 1

But it is evident that, everything aside, the way of wisdom is available to all. This is because it is not Nature that sets us on the path to vice; Nature generated us pure and free: Nulli nos vitio natura conciliat: illa integros ac liberos genuit (Ep. 94, 56).

Proficiens must therefore be thought of as receiving the correct precepts, and as being able to insert them in an educational project perfectly complying with Nature. Such proficiens will eventually gain his own independence and, in turn, will be able to explore new ways of teaching to others how best to become virtuous.

In another important letter, the 33, Seneca focuses on the following passage, directly facing his friend Lucilius and inviting him to take charge of his own responsibilities, to take charge of the possibility of exhibiting his own virtue:

Quousque disces? iam et praecipe. (...) Adice nunc quod isti qui numquam tutelae suae fiunt primum in ea re sequuntur priores in qua nemo non a priore descivit; deinde in ea re sequuntur quae adhuc quaeritur. Numquam autem invenietur, si contenti fuerimus inventis. Praeterea qui alium sequitur nihil invenit, immo nec quaerit. (Ep. 33, 9-10)

The key question appears immediately after: Quid ergo? non ibo per priorum vestigia?

The answer is extremely important. It indicates on one hand that every path of research can be improved and perfected; and on the other hand highlights the space left for research to become available to everyone. Individuals must equally pursue the $\operatorname{truth}^{22}$ for their own lives. And even if humanity as a whole has progressed greatly, there are still further territories to explore:

Quid ergo? non ibo per priorum vestigia? ego vero utar via vetere, sed si propiorem planioremque invenero, hanc muniam. Qui ante nos ista moverunt non domini nostri sed duces sunt. Patet omnibus veritas; nondum est occupata; multum ex illa etiam futuris relictum est. $($ Ep. 33,11$)$

Between decreta and praecepta the individual training continues, and in parallel, so does the teacherô job.

\footnotetext{
${ }^{22}$ On the conception of truth in Seneca, let me refer to Maso (2006a), pp. 153-84.
} 
Journal of Ancient Philosophy Vol. V 2011 Issue 1

Each must take charge of his own task and, most importantly, must take responsibility for his own decisions. The real teacher must take his own risks; he must know when to loosen or tighten the harness and, in so doing, he must consider the pupilôs character. But most of all he must know when it is the right moment to «leave» the harness to the pupil. For the pupil then, something similar occurs in parallel; he will have to understand when the right moment to independently from his teacher arises. Then he will no longer depend on his models, nec ad exempla pendere et totiens respicere ad magistrum (ep. 33, 8-9).

In the dimension of action we see the triumph of what was proposed by the theory of the Stoic doctrine. It can be a private or personal path, or an openly public and politic one. Regardless, the risk of «jumping» must be taken, and with it the responsibility.

Seneca, in a beautiful reinterpretation of the myth of Phaëton, alludes to the importance of decision making and to the risks associated with; (a) the adolescent reaching maturity; (b) the teacher (or the parent) assumption of the responsibility to stand aside and (c) the philosophical theory of Stoicism and the deterministic and providential structure that sustains him. This structure must be able to provide support against unforeseen shortcomings.

The aforementioned passage belongs to De providentia, a dialogue that has been problematic concerning the temporal collocation. However, beyond the doubts that persist, the global picture and the argumentations that spur the latest commentator $^{23}$ to propose a late dating (around 64) are convincing. That is, in parallel to the writing of Naturales quaestiones and of Epistulae, both dedicated to Lucilius. In my opinion this late dating sits comfortably with the meaning of the myth of Phaëton; a call to responsibility and to courage that whoever embraces Stoicism must demonstrate. So it is not an invitation to bear difficulties, pain and isolation but rather one to take and claim all the risks that are implicit in the arduous walk of virtus. As soon as the

${ }^{23}$ Cf. Lanzarone (2008), pp. 13-18. Neither Giancotti (1957), pp. 308-09, nor Griffin (1976), pp. 400-01, are able to solve the issue, for whom the dialogue results not datable. Also Dionigi (1994), pp. 5400-04, appears very undecided even if he considers the low dating «undoubtedly more credible». 
Journal of Ancient Philosophy Vol. V 2011 Issue 1

proficiens starts making his own decisions, he becomes «willing» and in harmony with the fate that anyway is meant for $\operatorname{him}^{24}$. This is a fate that belongs to «Nature» in its cosmic dimension, a fate that sees itself resolving any contradictory element; including the possible (but necessary) failures. In De prov. 5, 9-11 Seneca rhetorically questions the reason for godôs iniquitous allocation of fate among men, highlighting that good men often bear major blows of adverse fortune. The fact is that virtue is only virtuous if it is tested. Moreover, if it is true that the wise man only appears wise in the moment he displays his virtue through action, then the disgraces and misfortunes of life will appear decisive in order to be successful.

At this point, the adventure of Phaëton, the young adolescent, son of the Sun and of the Oceanid Clymene, is quoted. Phaëton, with a subterfuge managed to get his fathers permission to drive the cart, but eventually ended his race by falling into the Eridanus river (the Po). His sisters, the Heliades, met at the river and wept, eventually being transformed in poplars ${ }^{25}$. Senecaôs narration is particularly elaborate. Two passages of the text of Metamorphoses of Ovid (2, 63-69 e 79-81) are inserted, as a carving, but the tale, taken as a whole, is aimed at a different task. It begins from the same situation as the helmsman, who had a difficult job and has to keep the course against Fate. As a tenacious man he will have to face hardships:

Non erit illi planum iter: sursum oportet ac deorsum eat, fluctuetur ac navigium in turbido regat. Contra fortunam illi tenendus est cursus; multa accident dura, aspera, sed quae molliat et conplanet ipse. Ignis aurum probat, miseria fortes viros. (De prov. 5, 9)

Suddenly Seneca uses the second person as the means of narrative, and seems at first to refer to a generic interlocutor. However, as will become clear, he is in fact identifying himself with Zeus. The «you» is referred to Phaëton; Phaëton will have to learn that he will travel through unsafe places:

\footnotetext{
${ }^{24}$ This is the updated resumption of Stoic $\sigma v \gamma \kappa a \tau a ́ \theta \epsilon \sigma \iota s$ (of adsensum) stoica: non pareo deo, sed adsentior; ex animo illum, non quia necesse est, sequor (ep. 96, 2).

${ }^{25}$ Cf. Lanzarone (2008), pp. 370-72; I have had the opportunity to examine this passage also in respect of the Epicurean prospective: Maso (2007), pp. 269-78.
} 
Journal of Ancient Philosophy Vol. V 2011 Issue 1

Vide quam alte escendere debeat virtus: scies illi non per secura vadendum. (De prov. 5,10$)$

Quoting Ovid, Seneca proceeds presenting the risks and difficulties of the exploit. To this Phaëton retorts that he is attracted to danger and by the risk of falling:

Haec cum audisset ille generosus adulescens, ólacetôinquit óia, escendo; est tanti per ista ire casuroô (De prov. 5,11 )

For the last time his father Zeus intervenes; as the preceptor would do in his place. Zeus warns the pupil potential consequences for him. He admonishes him and tries to frighten him (territare $)^{26}$. But the praeceptum is not sufficient and, instead, has the opposite effect; in the end the adolescent makes his decision and embraces his fate without hesitation. It thus observes a young boldness (his quibus deterreri me putas incitor) and a even-handedness (libet illic stare ubi ipse Sol trepidat) within an ethical picture, that is noble and perfectly Stoic (per alta uirtus it):

Post haec ait: 'iunge datos currus: his quibus deterreri me putas incitor; libet illic stare ubi ipse Sol trepidat.' Humilis et inertis est tuta sectari: per alta uirtus it. (De prov. 5,11$)$

It is a manô task to take charge of his own condition. Learning this craft with a perfect cognition of causes under the sign of truth; this was the task of the pupil Nero, and perhaps Lucilius, but it definitely belonged to the wise stoic. The decision of Phaëton sets this approach in the dimension of the tragic and heroic; now his condition is comparable to that of Hercules, the hero that bears his destiny with the prospective of reaching the sky and the sky constellations ${ }^{27}$. That is truly recognising oneôs virtue and

\footnotetext{
${ }^{26} \mathrm{We}$ are in the imminence of the tragedy. It is important to compare this experience with the educational task of the tragedy. See above.

${ }^{27}$ As for Phaëton, for Hercules the way is also difficult: Non est ad astra mollis e terris via (Herc. f. 437). It is the journey that fate and Zeus firstly appear to refuse him: Quid astra, genitor, quid negas? (Herc. Oet. 13), but which virtue actually aims to: virtus in astra tendit, in mortem timor (Herc. Oet. 1971). And it is the same indication that, though methodically different, since youth Seneca had borrowed from the School of Sextii: Credamus itaque Sextio monstranti pulcherrimum iter et clamanti ónac itur ad astra, hac secundum frugalitatem, hac secundum temperantiam, hac secundum fortitudinem (ep. 73, 15).
} 
Journal of Ancient Philosophy Vol. V 2011 Issue 1

celebrating the Stoic ideal. With Phaëton and Hercules, the stoic sapiens aims to verify what he has understood to be the inescapable starting condition, that to «endanger» himself in the prospective of destiny. And so he matches his proper internal tension with the needs of development and realization of humanity. This is the line along which Stoic philosophy develops, in the moment that makes itself interpreter of the most radical sense of «risk», an operation that is both revolutionary and indispensable to existence $^{28}$.

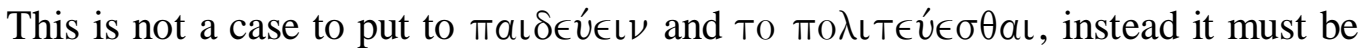
intertwined in the áctiveôinterpretation of Roman Seneca, if the original predisposition of the human subject is to be recognized in the social dimension: in spite of contradictions and compromises, despite the apparent refusals: but because of deeper and secret expectations.

Bibliography

Abel, K. 1985. ñSeneca. Leben und Leistungò, in Aufstieg und Niedergang der Römischen Welt, II, 32.2, De Gruyter, Berlin.

Alesse, F. 1994. Panezio di Rodi e la tradizione stoica, Bibliopolis, Napoli.

Bellincioni, M. 1978. Educazione alla sapientia in Seneca, Paideia, Brescia.

Bellincioni, M. 1984. Potere ed etica in Seneca, Paideia, Brescia.

Braund, S. Morton, 2009. Seneca, De clementia, edited with translation and commentary by S. M. B., Oxford.

Chaumartin, F.R. 1985. Le De Beneficiis de Sénèque: sa signification philosophique, politique et sociale, Les Belles Lettres, Lille-Paris.

Dingel, J. 1974. Seneca und die Dichtung, C. Winter, Heidelberg.

Dionigi, I. 1994. ñl đ́De Providentiaôdi Seneca fra lingua e filosofiaò, in Aufstieg und Niedergang der Römischen Welt, II, 36.7, De Gruyter, Berlin.

${ }^{28}$ For this I refer to Maso (2006c), pp. 190-93. 
Journal of Ancient Philosophy Vol. V 2011 Issue 1

Fitch, J.G., \& McElduff, S. 2008. ñConstruction of the Self in Senecan Dramaò, in Seneca. Oxford Reading in Classical Studies, J.F. Fitch ed., Oxford University Press, Oxford.

Giancotti, F. 1957. Cronologia dei Dialoghi di Seneca, Loescher, Torino.

Griffin, M.T. 1976. Seneca. A Philosopher in Politics, Oxford University Press, Oxford. Inwood, B. 1985. Ethics and Human Action in Early Stoicism, Clarendon Press, Oxford. Inwood, B. 2005. ñRules and Reasonning in Stoic Ethicsò, in Reading Seneca. Stoic Philosophy at Rome, Clarendon Press, Oxford.

Inwood, B. 2005a. ñThe Will in Senecaò, in Reading Seneca. Stoic Philosophy at Rome, Clarendon Press, Oxford.

Inwood, B. 2005b. ñSenecaô đe Beneficiisộ, in Reading Seneca. Stoic Philosophy at Rome, Clarendon Press, Oxford.

Ioppolo, A.M. 2000. ñóDecretaôe q́raeceptaôin Senecaò, in La filosofia in età imperiale, A. Brancacci ed., Bibliopolis, Napoli, pp. 15-36.

Lana, I. 1973. ñSextiorum nova et Romani roboris sectaò, in Studi sul pensiero politico classico, Guida, Napoli.

Lanzarone, N. 2008. L. Annaei Senecae, Dialogorum Liber I De providentia, a cura di N. L., Le Monnier, Firenze.

Long, A.A. 1971. ñFreedom and Determinism in the Stoic Theory of Human Actionò, in Problems in Stoicism, A.A. Long ed., Athlone Press, London.

Long, A.A. 1996. ñThe logical basis of Stoic ethics », in Stoic Studies, Cambridge University Press, Cambridge.

Malaspina, E., 2005. L. Annaei Senecae De clementia libri duo, prolegomeni, testo critico e commento a cura di E. M., Alessandria $\left(2001^{1}\right)$.

Maso, S. 2006. Le regard de la vérité. Cinq études sur Sénèque, LôHarmattan, Paris.

Maso, S. 2006a. ñSénèque et le mécanisme de la véritéò, in Le regard de la vérité. Cinq études sur Sénèque, Lơ̂armattan, Paris.

Maso, S. 2006c. Fondements philosophiques du risque, LâHarmattan, Paris.

Maso, S. 2007. ñóEst tanti per ista ire casuroô lôOccidente e lấsperienza del piacere e del doloreò, in Saperi umani e consulenza filosofica, V. Gessa Kurotschka and G.

Cacciatore eds., Meltemi, Roma.

Pohlenz, M. 1992. Die Stoa. Geschichte einer geistigen Bewegung, Vandenhoek \& Ruprecht, Göttingen (VII Auflage; erste Ausgabe: 1949).

Préchac, F. 1972. ñntroductionòà Sénèque. Des bienfaits, texte établi et traduit par F. P., Les Belles Lettres, Paris (éd. or. 1926).

Schafer, J. 2009. Ars Didactica. Senecaôs $94^{\text {th }}$ and $95^{\text {th }}$ Letters, Vandenhoeck \& Ruprecht, Göttingen. 
Journal of Ancient Philosophy Vol. V 2011 Issue 1

H.H. Scullard, From the Gracchi to Nero. A History of Rome from 133 B.C. to A.D. 68, Methuen \& Co., London $1970^{3}$ (1959).

Viansino, G. 2007. ñTesto critico, introduzione e commentoòa Seneca, Teatro, Mondadori, Milano (prima ed. 1993). 